\title{
Pengaruh Usia Ibu Hamil terhadap Jumlah Sel Punca Hematopoietik dan Very Small Embryonic-like Stem Cell pada Darah Tali Pusat
}

\author{
Angliana Chouw ${ }^{1,2}$, Bayu W. Putera ${ }^{2}$, Cynthia R. Sartika ${ }^{2}$, Ajeng Diantini ${ }^{1}$, \\ Tono Djuwantono ${ }^{3}$, Ahmad Faried ${ }^{4}$, Dwi A. P. Dewi ${ }^{2}$, Julia Riswandani ${ }^{2}$ \\ ${ }^{1}$ Fakultas Farmasi, Universitas Padjajaran, Bandung, Indonesia, ${ }^{2} \mathrm{PT}$. Prodia StemCell \\ Indonesia, Jakarta, Indonesia, ${ }^{3}$ Departemen Obsteri dan Ginekologi, Fakultas Kedokteran, \\ Universitas Padjajaran, Bandung, Indonesia, ${ }^{4}$ Stem Cell Working Group, \\ Fakultas Kedokteran, Universitas Padjajaran, Bandung, Indonesia
}

\begin{abstract}
Abstrak
Darah tali pusat telah banyak digunakan dalam terapi regeneratif. Hal ini disebabkan darah tali pusat mengandung sel punca, yaitu sel punca hematopoietik dan very small embryonic-like stem cell. Keberhasilan terapi regeneratif menggunakan darah tali pusat membutuhkan dosis yang disesuaikan dengan berat badan dan cara pemberian sel punca. Oleh karena itu, dibutuhkan informasi yang dapat memengaruhi jumlah sel punca yang ada pada darah tali pusat. Usia ibu pada saat kehamilan diperkirakan memiliki pengaruh terhadap jumlah sel punca. Penelitian ini dilakukan dengan pendekatan studi potong lintang. Penelitian dilakukan di Laboratorium Prodia StemCell Indonesia pada bulan Desember 2017. Sebanyak 22 sampel yang digunakan dalam penelitian ini merupakan darah tali pusat yang telah disimpan sebelumnya selama lebih dari dua tahun. Deteksi jumlah sel hematopoietik dan very small embryoniclike stem cell dilakukan dengan menggunakan metode flowcytometry. Deteksi sel punca hematopoietik dilakukan dengan menggunakan molekul penanda permukaan CD34+ dan CD45+, sedangkan deteksi very small embryonic-like stem cell dilakukan dengan menggunakan molekul penanda permukaan CD45-, CD34+, dan CD184(CXCR4)+. Pada kelompok usia ibu di atas 30 tahun, rata-rata jumlah sel hematopoietik adalah $63,71 \pm 58.419 \times 10^{3} \mathrm{sel} / \mathrm{mL}$ dan rata-rata jumlah very small embryonic-like stem cell adalah $7,83 \pm 7.060 \times 10^{3} \mathrm{sel} / \mathrm{mL}$. Uji beda menunjukkan semakin tua usia ibu pada saat kehamilan, jumlah sel punca semakin meningkat, namun tidak ada perbedaan yang signifikan $(r=0,0510 ; p<0,005)$. Hal ini menunjukkan bahwa usia ibu tidak memengaruhi konsentrasi sel darah tali pusat.
\end{abstract}

Kata kunci: Darah tali pusat, sel hematopoietik, sel punca, very small embryonic-like stem cell

\section{Influence of Maternal Age on Hematopoietic Stem Cell and Very Small Embryonic-like Stem Cell Concentration in Umbilical Cord Blood}

\begin{abstract}
Umbilical cord blood (UCB) has been used in regenerative medicine due to the stem cell content in the blood. Hematopoietic stem cell and very small embryonic-like stem cell are found in UCB sample. Dosage and route of administration of stem cell need to be determined for the success of regenerative therapy. Therefore, information that can affect the stem cell number is needed. This study used crosssectional approach, and was conducted at Prodia StemCell Laboratory in December 2017. Twenty-two UCB samples collected from Prodia StemCell Laboratory which had been stored for more than 2 years were thawed to detect the number of stem cell. Flowcytometry method was used to detect the number of hematopoietic stem cell and very small embryonic-like stem cell in UCB sample. Hematopoietic stem cell was detected using antibody CD34+ and CD45+ while very small embryonic-like stem cell was detected using CD45-, CD34+, and CD184(CXCR4)+. The mean cell number of hematopoietic stem cell and very small embryonic-like stem cell in maternal age above 30 years old group were 63.71 $\pm 58.419 \times 10^{3} \mathrm{cell} / \mathrm{mL}$ and $7.83 \pm 7.060 \times 10^{3} \mathrm{cell} / \mathrm{mL}$, respectively. There was no significant difference in maternal age group during pregnancy $(\mathrm{r}=0.0510 ; \mathrm{p}<0.005)$. In conclusion, the number of cells in umbilical cord blood due to the number of blood cell is not related to maternal age.
\end{abstract}

Keywords: Hematopoeitic stem cell, stem cell, umbilical cord blood, very small embryonic-like stem cell

Korespondensi: Angliana Chouw, M.Farm, Fakultas Farmasi, Universitas Padjajaran, Bandung, Jawa Barat 40161, Indonesia, email: 1chouw@gmail.com

Naskah diterima: 6 Februari 2018, Diterima untuk diterbitkan: 13 Mei 2019, Diterbitkan: 28 Juni 2019 


\section{Pendahuluan}

Sejak keberhasilan transplantasi darah tali pusat yang dilakukan pada penderita anemia Fanconi pada tahun 1988, darah tali pusat banyak digunakan dalam terapi regeneratif. Terapi regeneratif yang telah dilakukan tidak hanya terbatas pada kelainan darah saja. ${ }^{1}$ Telah banyak uji klinis yang menggunakan sel punca untuk mengobati penyakit lainnya, seperti gangguan sistem imun, gangguan neurologis, gangguan jantung, serta gangguan persendian. ${ }^{2-4}$ Darah tali pusat mengandung sel punca hematopoietik (hematopoietic stem cell/HSC) dan jenis sel punca lain, seperti very small embryonic-like stem cell (VSEL). ${ }^{5}$ Sel punca merupakan sel yang mampu memperbanyak dirinya dan berdiferensiasi menjadi sel lain yang ada di dalam tubuh. Setiap sel punca memiliki perannya masing-masing dalam proses terapi regeneratif. ${ }^{6}$ Sel punca hematopoietik merupakan sel punca dewasa yang mempunyai kemampuan multipotensi dan juga dapat memperbanyak dirinya. Sel punca hematopoietik berperan dalam proses hematopoiesis yaitu melakukan pertahanan jumlah sel darah di dalam tubuh dengan cara memperbanyak dan berdiferensiasi dalam garis turunannya. ${ }^{7}$ VSEL merupakan sumber alternatif untuk sel punca pluripoten karena memiliki kemampuan untuk berdiferensiasi menjadi 3 germ layer. VSEL memerankan fungsi untuk rejuvenasi sel dewasa dalam proses regenerasi. VSEL dapat berdiferensiasi dan mengakibatkan peningkatan populasi sel punca hematopoietik yang bersifat jangka panjang (long-term HSC). ${ }^{8}$

Keberhasilan terapi regeneratif dengan menggunakan sel punca dipengaruhi oleh rute pemberian dan dosis sel yang sesuai dengan kebutuhan yang diperlukan. Selain itu, sel yang digunakan dalam terapi regeneratif haruslah sel yang mencukupi kebutuhan dan mampu bekerja secara optimal. ${ }^{9}$ Proses mendapatkan sel punca yang berasal dari darah tali pusat dapat dipengaruhi oleh faktor maternal pada saat kehamilan. Salah satu faktor maternal yang dapat memengaruhi jumlah sel yang terkandung dalam darah tali pusat adalah usia ibu pada saat kehamilan. Semakin tua usia ibu, semakin besar pula risiko komplikasi yang terjadi baik terhadap ibu maupun bayi. ${ }^{10}$ Oleh karena itu, penelitian ini bertujuan untuk melihat pengaruh usia ibu terhadap jumlah sel punca yang ada di dalam darah tali pusat.

\section{Metode}

Penelitian ini telah disetujui oleh Komisi Etik Penelitian Kesehatan Fakultas Kedokteran Universitas Padjadjaran (No. 1001/UN6/C10/ PN/2017). Subjek penelitian merupakan ibu hamil dengan kriteria inklusi sebagai berikut: 1) Usia ibu 17-39 tahun; 2) Usia kehamilan 37-40 minggu yang merupakan kelahiran aterm; 3) Hasil screening darah ibu bebas dari penyakit infeksius berdasarkan standar America Association Blood Bank (AABB), yaitu: Human Immunodeficiency Virus (HIV), Hepatitis B, Hepatitis C, Cytomegalovirus (CMV), Venereal Disease Research Laboratory (VDRL), dan Trepanoma Pallidum Hemaglutination Assay (TPHA)

Deteksi sel punca hematopoietik dan VSEL Darah tali pusat yang telah diperiksa antiHIV, anti-HBs, anti-CMV IgM, TPHA/VDRL, dan lulus screening diproses di Laboratorium PT. Prodia Stem Cell. Darah tali pusat diproses dengan menggunakan metode pembentukan rouleaux oleh hydroxyethyl starch (HES) untuk mengisolasi sel punca. Kriopreservasi dilakukan dengan menambahkan larutan DMSO $10 \%$, dan sampel disimpan beku pada suhu di bawah $-150^{\circ} \mathrm{C}$ pada fase uap nitrogen cair. Sampel yang telah disimpan selama lebih dari dua tahun dikeluarkan dan dicairkan pada suhu $37^{\circ} \mathrm{C}$. Sebanyak $100 \mu$ sampel dimasukkan ke dalam tabung BD Trucount tube (BD Bioscience, San Jose, CA), lalu 
ditambahkan antibodi $20 \mu \mathrm{l} \mathrm{CD} 34-\mathrm{PE} / \mathrm{CD} 45-$ FITC (BD Bioscience, San Jose, CA), dan 10 $\mu 1$ CD184 (CXCR4)-PE.Vio770 (Miltenyi Biotec GmbH, Bergish Gladbach, Germany). Sampel kemudian diinkubasi selama 30 menit pada suhu ruang dalam kondisi gelap, lalu ditambahkan $2 \mathrm{~mL}$ BD FACS Lysing Solution 1x (BD Bioscience, San Jose, CA) dan diinkubasi selama 10 menit pada suhu ruang. Sampel kemudian dibaca pada mesin flowsitometer BD FACS CANTO II. Deteksi sel punca hematopoietik dilakukan dengan menggunakan molekul penanda permukaan CD34+ dan CD45+, sedangkan deteksi VSEL dilakukan dengan menggunakan molekul penanda permukaan CD45-, CD34+, dan CD184(CXCR4)+.

Perhitungan jumlah sel

Perhitungan jumlah sel dilakukan berdasarkan rumus pada instruksi manual:

Jumlah sel $=\frac{\text { Jumlah event cell positif }}{\text { Jumlah event bead }} \times \frac{\text { Jumlah bead dalam trucount }}{\text { Volume sampel }}$

Keterangan:

(1) Jumlah event cell positif: jumlah sel yang positif terhadap penanda antibodi spesifik pada hasil pembacaan flowsitometri;

(2) Jumlah bead dalam trucount: partikel dengan konsentrasi yang telah ditetapkan sebelumnya pada tabung trucount untuk perhitungan konsentrasi sel pada sampel;

(3) Jumlah event bead: jumlah partikel pada tabung trucount pada hasil pembacaan flowsitometri; dan
(4) Volume sampel: volume sampel yang digunakan dalam preparasi sampel.

Analisis data

Analisis data dilakukan dengan menggunakan perangkat lunak SPSS versi 24 pada sistem operasi Windows dengan standar kesalahan sebesar 5\%. Uji korelasi dilakukan dengan menggunakan metode Spearman sebab sebaran data tidak normal. Uji beda dilakukan dengan menggunakan Kruskal-Wallis.

\section{Hasil}

Sebanyak 22 sampel darah tali pusat yang terkumpul pada penelitian ini diperoleh dari ibu hamil dengan usia ibu 17-39 tahun dan usia kehamilan aterm yang berkisar antara 37-40 minggu. Usia ibu pada saat kehamilan dikelompokkan berdasarkan pada persebaran data yang diperoleh pada penelitian. Nilai tengah yang didapatkan yaitu usia 28 tahun, sedangkan kuartil 1 yaitu 26 tahun dan kuartil 3 adalah 30 tahun. Untuk melihat pengaruh usia ibu terhadap jumlah sel punca yang ada di dalam darah tali pusat, dilakukan analisis pada berbagai kelompok usia (Tabel 1).

Berdasarkan Gambar 1, rata-rata jumlah sel punca hematopoietik dan VSEL pada setiap kelompok usia meningkat seiring dengan bertambahnya usia. Uji beda yang dilakukan terhadap peningkatan jumlah sel menunjukkan adanya perbedaan yang tidak signifikan.

Uji korelasi yang dilakukan untuk melihat

Tabel 1 Hubungan Jumlah Sel Punca terhadap Kelompok Usia

\begin{tabular}{|c|c|c|c|c|}
\hline \multirow[b]{2}{*}{ Variabel } & \multicolumn{4}{|c|}{ Kelompok Usia } \\
\hline & $\begin{array}{c}\leq 26 \text { tahun } \\
(n=5) \\
M e a n \pm \text { SD }\end{array}$ & $\begin{array}{c}27-30 \text { tahun } \\
(\mathrm{n}=12) \\
\operatorname{Mean} \pm \mathrm{SD}\end{array}$ & $\begin{array}{c}\geq 31 \text { tahun } \\
\quad(n=5) \\
M e a n \pm \text { SD }\end{array}$ & Nilai $p$ \\
\hline Umur (tahun) & $22 \pm 4$ & $28 \pm 1$ & $36 \pm 1$ & $0,000^{*}$ \\
\hline Usia kehamilan (minggu) & $38 \pm 1$ & $38 \pm 1$ & $38 \pm 1$ & 0,498 \\
\hline Sel punca hematopoietik (103 sel/mL) & $17,82 \pm 8,568$ & $31,33 \pm 23,138$ & $63,71 \pm 58,419$ & 0,253 \\
\hline Very small embryonic-like stem cell $(103 \mathrm{sel} / \mathrm{mL})$ & $2,51 \pm 1,634$ & $4,94 \pm 6,171$ & $7,83 \pm 7,060$ & 0,402 \\
\hline
\end{tabular}




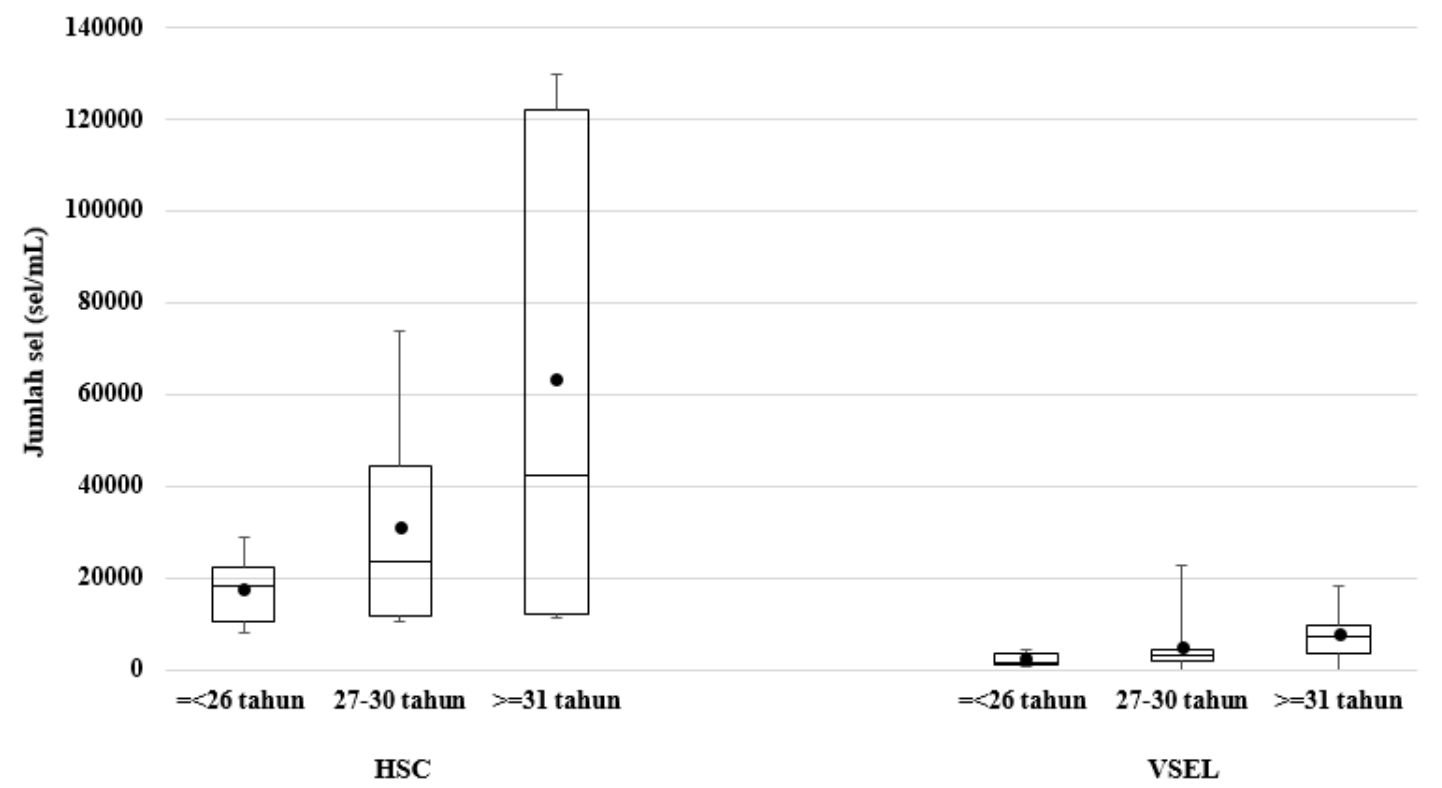

Gambar 1 Grafik Boxplot Rata-Rata Jumlah Hematopoietic Stem Cell (HSC) dan Very Small Embryonic-like Stem Cell (VSEL) pada Setiap Kelompok Usia

apakah VSEL berpotensi untuk berdiferensiasi menjadi sel punca hematopoietik dilakukan dengan melihat korelasi terhadap jumlah sel punca hematopoietik dan VSEL. Hasil uji korelasi tersebut menunjukkan adanya korelasi positif signifikan $(\mathrm{p}<0.005)$ dengan nilai $\mathrm{r}=0.510$ (Gambar 2).

\section{Pembahasan}

Deteksi jumlah sel punca hematopoietik dan VSEL dilakukan pada darah tali pusat yang telah disimpan dan diolah sebelumnya di Laboratorium Prodia StemCell Indonesia. Darah tali pusat dengan volume sampel

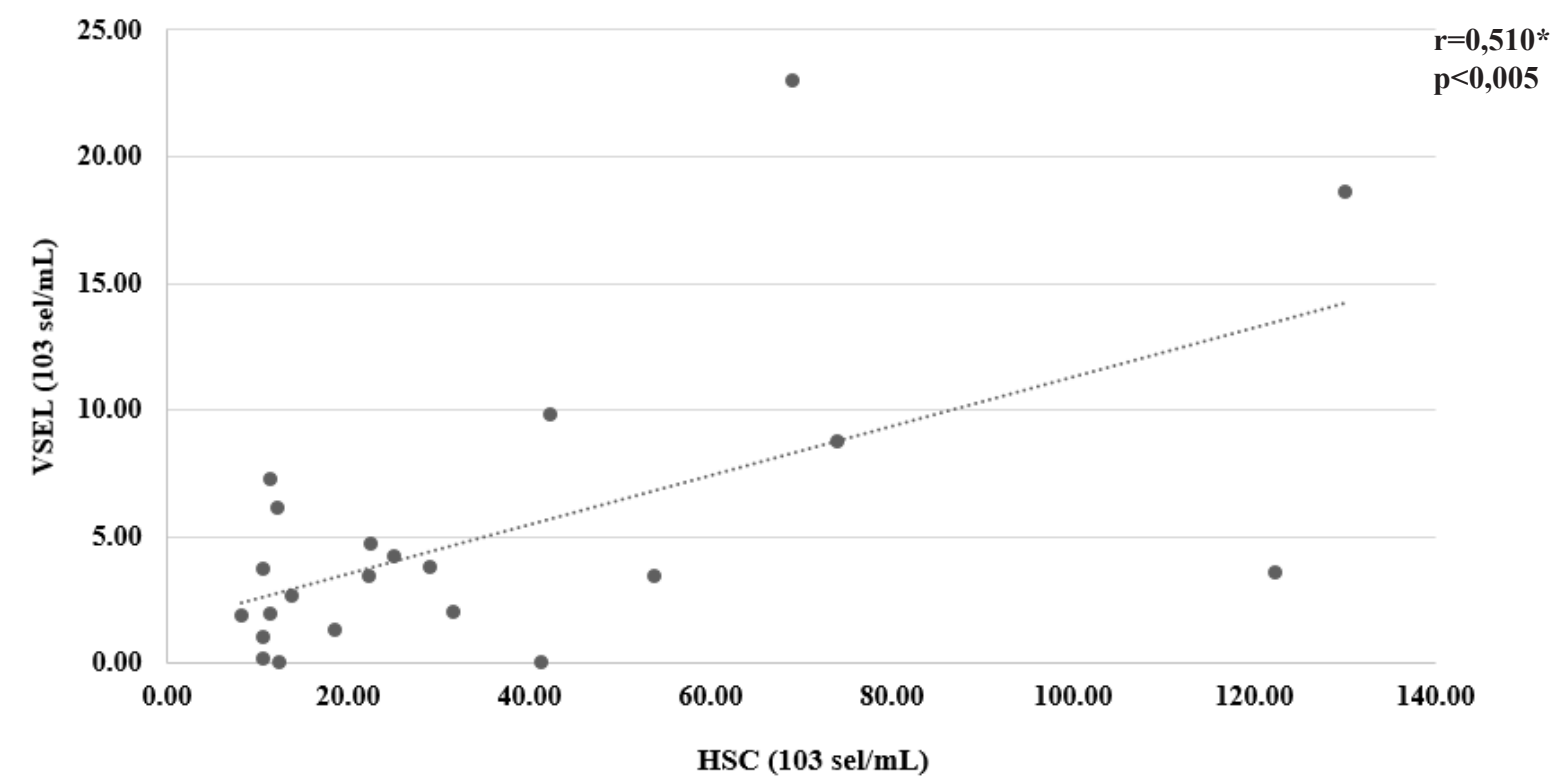

Gambar 2 Grafik Korelasi Jumlah Hematopoietic Stem Cell (HSC) dan Very Small Embryonic-like Stem Cell (VSEL) 
berkisar antara 25,94-123,68 mL yang diproses dengan menggunakan metode volume reduksi hingga menjadi $25 \mathrm{~mL}$ produk akhir. Standar deviasi dari jumlah hematopoietik dan VSEL sangat besar. Hal ini dapat dipengaruhi oleh ketidakseragaman volume awal sampel. ${ }^{11}$

Uji beda yang dilakukan antara kelompok usia ibu menunjukkan tidak ada perbedaan dengan jumlah sel punca hematopoietik dan VSEL yang ada di dalam darah tali pusat. Penelitian sebelumnya yang dilakukan oleh Bielec-Berek et al. menunjukkan bahwa usia ibu memengaruhi jumlah sel darah putih. ${ }^{12}$ Pada kehamilan dengan usia ibu di atas 31 tahun, jumlah sel darah putih lebih banyak dibandingkan usia ibu di bawah 25 tahun. Sel punca darah tali pusat merupakan populasi sel yang berada pada sel darah putih. Akan tetapi, pada penelitian tersebut dikatakan pula bahwa pada sel hematopoietik, tidak terdapat pengaruh usia ibu hamil terhadap jumlah sel punca hematopoietik. ${ }^{13}$ Berbeda dengan hasil studi Mazzoccoli et al., jumlah sel seperti total sel berinti (TNC) dan CD34+ tidak memiliki perbedaan yang signifikan jika dibandingkan usia ibu pada saat kehamilan, namun memiliki perbedaan terhadap usia kehamilan. ${ }^{14}$ Faktor lainnya, seperti proses kelahiran, juga dapat memengaruhi jumlah sel punca yang ada. Hal ini disebabkan tubuh secara alami merespon stres oksidatif dan faktor lain yang ada.

Hasil uji korelasi yang dilakukan antara jumlah sel punca hematopoietik dan VSEL menunjukkan korelasi yang positif. Uji ini dilakukan untuk melihat kemampuan VSEL dalam berdiferensiasi menjadi sel punca hematopoietik, hal ini karena VSEL bersifat pluripoten yang memiliki kemampuan untuk berdiferensiasi menjadi seluruh sel yang ada di dalam tubuh. VSEL memiliki fungsi kerja dalam menjaga keseimbangan jumlah sel yang ada di dalam tubuh. Apabila tubuh mengalami luka, tubuh akan mengeluarkan sitokin yang akan merangsang VSEL untuk berdiferensiasi menjadi tissue committed stem cell (TCSC). ${ }^{14,15}$ Salah satu jenis TCSC adalah sel punca hematopoietik. VSEL akan berdiferensiasi menjadi sel punca hematopoietik yang bersifat jangka panjang atau dikenal dengan istilah long-term hematopoietic stem cell. ${ }^{8}$

Keterbatasan dalam penelitian ini adalah jumlah sampel yang tidak merata pada setiap kelompok usia, dan jumlah volume sampel yang diperoleh saat pengambilan darah tali pusat tidak seragam. Semakin tinggi volume sel yang diperoleh saat pengambilan darah tali pusat, semakin meningkat jumlah sel punca yang ada pada akhir produk darah tali pusat yang disimpan. Oleh karena itu, sebaiknya dilakukan standarisasi volume awal darah tali pusat sebelum dilakukan metode volume reduksi. Adapun kelebihan dari penelitian ini adalah dilakukannya perhitungan jumlah sel VSEL dengan menggunakan metode enumerasi, sehingga dapat dilihat jumlah sel pada setiap $\mathrm{mL}$ sampel.

Penelitian mengenai VSEL merupakan hal yang baru dikembangkan pada tahun 2008 . Ratajczak et al. pertama kali mengidentifikasi adanya sel yang bersifat pluripoten pada sum -sum tulang belakang. ${ }^{8}$ Publikasi mengenai VSEL masih tergolong sedikit dan tengah dikembangkan dari berbagai sumber lainnya. Terkait sel punca hematopoietik, aplikasi klinis dari transplantasi klinis telah banyak dilakukan. Namun, penelitian masih terus dikembangkan untuk mencari sumber sel punca yang baik digunakan. Oleh karena itu, penelitian ini diharapkan dapat memberikan informasi mengenai sumber sel punca yang baik digunakan dilihat dari sumber sel punca dan krtieria donor berdasarkan usia ibu.

\section{Simpulan}

Usia ibu saat kehamilan tidak berpengaruh terhadap jumlah sel punca hematopoietik (HSC) dan very small embryonic-like stem cell (VSEL) yang terdapat pada darah tali 
pusat. Usia ibu di atas 30 tahun memiliki konsentrasi sel punca yang paling besar, yaitu $63,71 \pm 58,419$ sel $\mathrm{HSC} / \mathrm{mL}$ dan 7,83 $\pm 7,060$ sel VSEL/mL. Terdapat korelasi positif antara VSEL dan sel punca hematopoietik.

\section{Ucapan Terima Kasih}

Terima kasih kepada PT. Prodia StemCell Indonesia dan PT. Prodia Widyahusada sebagai tempat penyelenggaraan penelitian.

\section{Pendanaan}

Penelitian ini mendapatkan bantuan dana seluruhnya dari PT. Prodia Utama.

\section{Konflik Kepentingan}

Seluruh penulis menyatakan tidak terdapat potensi konflik kepentingan dengan penelitian, kepenulisan (authorship), dan atau publikasi artikel ini

\section{Daftar Pustaka}

1. Min K, Song J, Kang JY, Ko J, Ryu JS, Kang MS, et al. Umbilical cord blood therapy potentiated with erythropoietin for children with cerebral palsy: A Doubleblind, randomized, placebo-controlled Trial. Stem Cells Dayt Ohio. 2013;31(3):581-91. doi: 10.1002/stem.1304.

2. Kong L, Zheng L-Z, Qin L, Ho KKW. Role of mesenchymal stem cells in osteoarthritis treatment. J Orthop Transl. 2017;9:89-103. doi: 10.1016/j.jot.20 17. 03.006 .

3. Wang LT, Ting CH, Yen ML, Liu KJ, Sytwu $\mathrm{HK}, \mathrm{Wu} \mathrm{KK}$, et al. Human mesenchymal stem cells (MSCs) for treatment towards immune- and inflammation-mediated diseases: Review of current clinical trials. J Biomed Sci. 2016;23:76. doi: 10.1186/ s12929-016-0289-5
4. Darmayanti S, Triana R, Chouw A, Dewi NM. Is stem cell a curer or an obstruction? Mol Cell Biomed Sci. 2017;1(1):17-27. doi: 10.21705/mcbs.v1i1.12

5. Danova-Alt R, Heider A, Egger D, Cross M, Alt R. Very small embryonic-like stem cells purified from umbilical cord blood lack stem cell characteristics. PLoS One. 2012;7(4):1-11. doi: 10.1371/journal.pon e.0034899

6. Mahla RS. Stem cells applications in regenerative medicine and disease therapeutics. Int J Cell Biol. 2016;2016: 6940283. doi: 10.1155/2016/6 940283.

7. Ng AP, Alexander WS. Haematopoietic stem cells: Past, present and future. Cell Death Discov. 2017;3:17002. doi: 10.103 8/cddiscovery.2017.2.

8. Ratajczak MZ, Zuba-Surma E, Wojakowski W, Suszynska M, Mierzejewska K, Liu R, et al. Very small embryonic-like stem cells (VSELs) represent a real challenge in stem cell biology: Recent pros and cons in the midst of a lively debate. Leukemia. 2014; 28(3):473-84. doi: 10.1038/leu.2013.255.

9. Golpanian S, Schulman IH, Ebert RF, Heldman AW, DiFede DL, Yang PC, et al. Concise review: Review and perspective of cell dosage and routes of administration from preclinical and clinical studies of stem cell therapy for heart disease. Stem Cells Transl Med. 2016;5(2):186-91. doi: 10.5966/sctm.2015-0101

10. Cavazos-Rehg PA, Krauss MJ, Spitznagel EL, Bommarito K, Madden T, Olsen MA, et al. Maternal age and risk of labor and delivery complications. Matern Child Health J. 2015;19(6):1202-11. doi: 10.10 07/s10 995-014-1624-7.

11. Solves P, Planelles D, Mirabet V, Blanquer A, Carbonell-Uberos F. Qualitative and quantitative cell recovery in umbilical cord blood processed by two automated devices in routine cord blood banking: A comparative study. Blood Transfus. 2013. 
11(3):405-11. doi: 10.2450/2012.0037-12.

12. Bielec-Berek B, Jastrzębska-Stojko Ż,

Drosdzol-Cop A, Jendyk C, Boruczkowski

$\mathrm{D}$, Ołdak T, et al. Maternal predictors and quality of umbilical cord blood units. Cell Tissue Bank. 2018; 19(1): 69-75. doi: 10. 1007/s10561-017-9657-y

13. Mazzoccoli G, Miscio G, Fontana A, Copetti M, Francavilla M, Bosi A, et al. Time related variations in stem cell harvesting of umbilical cord blood. Sci Rep. 2016;6:21404. doi: 10.1038/srep214 04
14. Shin DM, Suszynska M, Mierzejewska K, Ratajczak J, Ratajczak MZ. Very small embryonic-like stem-cell optimization of isolation protocols: An update of molecular signatures and a review of current in vivo applications. Exp Mol Med. 2013;45(11):e56. doi: 10.1038/em m.2 013.117 .

15. Maltman DJ, Hardy SA, Przyborski SA. Role of mesenchymal stem cells in neurogenesis and nervous system repair. Neurochem Int. 2011;59(3):347-56. doi: 10.1016/j.neuint.2011.06.008.

(C) 2019 Chouw et al. The full terms of this license incorporate the Creative Common Attribution-Non Commercial License (https://creative commons.org/licenses/by-nc/4.0/). By accessing the work you hereby accept the terms. Non-commercial use of the work are permitted without any further permission, provided the work is properly attributed. 